\title{
Baclofen Attenuates the Reinforcing Effects of Cocaine in Rats
}

David C. S. Roberts, Ph.D., Monique M. Andrews, M.Sc., and Gary J. Vickers, M.Sc.

The effect of the $G A B A_{B}$ agonist baclofen on cocaine selfadministration in the rat was investigated. In the first experiment, rats trained to self-administer IV cocaine (1.5 $\mathrm{mg} / \mathrm{kg} / \mathrm{inj}$ ) on a progressive ratio (PR) schedule were pretreated with various doses of baclofen $(1.25,2.5$, or 5.0 $\mathrm{mg} / \mathrm{kg}$ ). Baclofen produced a dose-dependent decrease in the break points. In the second experiment, baclofen $(2.5 \mathrm{mg} / \mathrm{kg})$ was found to decrease significantly break points across a series of unit injection doses of cocaine $(0.18,0.37,0.75,1.5$ $\mathrm{mg} / \mathrm{kg} / \mathrm{inj})$. Baclofen produced only modest effects on food- reinforced responding even at the largest dose tested (5.0 $\mathrm{mg} / \mathrm{kg}$ ). These data suggest that baclofen may produce a specific attenuation of cocaine reinforcement. Baclofen produced no significant change in the rate of IV cocaine intake on a fixed ratio (FR 1) schedule. These data support a number of recent observations that rate of drug intake may be an insensitive measure of changes in the motivation to self-administer cocaine. [Neuropsychopharmacology 15:417-423, 1996]
KEY WORDS: Cocaine; Self-Administration; Baclofen; Addiction; GABA

The site of action for the reinforcing effects of cocaine appears to be on dopaminergic terminals within the nucleus accumbens and other mesocortical areas (Johanson and Fischman 1989; Koob 1992; Roberts 1992; Woolverton and Johnson 1992). Cocaine blocks the reuptake of catecholamines into the presynaptic element, thus acting as an indirect agonist at noradrenaline, serotonin, and dopamine (DA) synapses. Considerable data now indicate that the dopaminergic effect is of primary importance. Neurotoxic lesions of the DA innervation of the accumbens or elimination of the DA projection neurons within the ventral tegmental area dramatically disrupts cocaine self-administration in rats (Zito et al. 1985; Roberts et al. 1977; Roberts et al. 1980). Pharmaco-

From the Institute of Neuroscience, Carleton University, Ottawa, Canada.

Address correspondence to: Dr. D. C. S. Roberts, Life Sciences Research Centre, Carleton University, 1125 Colonel By Drive, Ottawa, Canada, K1S 5B6.

Received September 25; revised December 14, 1995; accepted December 20, 1995. logical evidence also supports a primary role for DA. Dopamine antagonists administered either systemically (Woolverton 1986; De Wit and Wise 1977; Hubner and Moreton 1991; Caine and Koob 1994; Roberts and Vickers 1984) or directly into the nucleus accumbens (McGregor and Roberts 1993; Maldonado et al. 1993) attenuate the reinforcing effects of cocaine. Furthermore, the relative reinforcing efficacy of various cocaine analogues correlates with their binding affinity to the dopamine transporter (Ritz et al. 1987).

Whereas dopamine terminals may be the primary site of action, the reinforcing effects might be influenced by manipulation of other neurotransmitter systems that interconnect with DA systems. GABA is one such transmitter with extensive interactions with DA. Eighty percent of the neurons within the nucleus accumbens are GABAergic (Kita and Kitai 1988), and they presumably receive the cocaine-potentiated dopaminergic signal. GABA neurons also project back to DA cells within the ventral tegmental area (VTA) to regulate their activity. Pharmacological manipulation of GABA systems has powerful effects on DA release and on DA cell firing (Klitenick et al. 1992; Cameron and Williams 1993; Engberg et al. 1993; Seutin et al. 1994; Santiago et al. 1993a, 
1993b, 1993c; Rick and Lacey 1994; Westerink et al. 1992; Yoshida et al. 1994).

Despite the clear evidence for DA/GABA interactions, little is known about the effects of GABA drugs on cocaine reinforcement. Three types of GABA receptors are known. The bicuculline-sensitive $\mathrm{GABA}_{\mathrm{A}}$ receptor is coupled to a chloride channel and is associated with multiple binding sites with high affinities for benzodiazepines, barbiturates, picrotoxin, and centrally active steroids. The bicuculline-insensitive $\mathrm{GABA}_{B}$ receptor is coupled to potassium and calcium channels through G-proteins and second messengers. A pharmacologically distinct $\mathrm{GABA}_{C}$ receptor has also been described (Bormann and Feigenspan 1995). There have been no reports on the effects of direct GABA agonists or antagonists on cocaine reinforcement. A modulatory role for the $\mathrm{GABA}_{\mathrm{A}}$ receptor is suggested by the demonstration that the benzodiazepines, chlordiazepoxide and alprazolam, both reduce the rate of cocaine self-administration reinforced on fixed ratio schedules (Goeders et al. $1989,1993)$. This appears to represent a potentiation of the reinforcing efficacy of cocaine, because animals will respond to higher break points on a progressive ratio (PR) schedule for cocaine reinforcement after chlordiazepoxide pretreatment (Roberts and Vickers, in preparation). The effects of pharmacological manipulation of $\mathrm{GABA}_{\mathrm{B}}$ receptors on cocaine reinforcement have not yet been described.

In the present experiments we examined the effect of the $\mathrm{GABA}_{\mathrm{B}}$ agonist baclofen on cocaine self-administration behavior in rats reinforced on a PR schedule.

\section{METHODS}

Subjects were male Wistar rats (Charles River Farms, Quebec) weighing 275 to $300 \mathrm{~g}$ at the start of the experiment. One week after their arrival from the supplier, rats were food deprived for 24 hours then trained to press a lever for food reinforcement on a fixed ratio (FRI) schedule. Thereafter food was available ad libitum. Each rat was implanted with a chronically indwelling Silastic jugular cannula that exited through the skin on the dorsal surface in the region of the scapulae (Roberts and Goeders 1989). After cannulation, each rat was singly housed in $25 \times 25 \times 25 \mathrm{~cm}$ operant testing apparatus. The cannula was mounted on a counterbalanced swivel apparatus, which allowed free movement within the operant chamber.

Rats were given access to a response lever for a 5 -hour period each day. Each lever response activated an injection pump, delivering $0.12 \mathrm{ml}$ of saline solution containing $0.6 \mathrm{mg} / \mathrm{ml}$ of cocaine $\mathrm{HCl}$ over a 5-second period. Concurrent with the start of the injection, a stimulus light was activated that signaled a 20 -second post-infusion time-out period during which time responses produced no programmed consequence.

\section{Experiment 1}

Twelve rats that had demonstrated a constant rate of responding on the FR 1 schedule ( $>30 \mathrm{inj} / 5$ hours and regular postinfusion pauses) were given access to cocaine $(1.5 \mathrm{mg} / \mathrm{kg} / \mathrm{inj})$ on a PR schedule. Each rat received one priming injection at the start of each daily session. The next reinforcement was contingent on a single lever response; thereafter the number of responses required to obtain subsequent infusions was incremented through the following progression: 1, 2, 4, 6, $9,12,15,20,25,32,40,50,62,77,95,118,145,178,219$, $268,328,402,492,603$. This implementation has been described in detail elsewhere (Roberts and Richardson 1995). The session continued until the subject failed to obtain an infusion for a 1-hour period. Break point was defined by the number of completed increments in the schedule.

The effect of $( \pm)$-baclofen pretreatment $(1.25,2.5$ or $5.0 \mathrm{mg} / \mathrm{kg}$, IP, 30 minutes before the session) was investigated in animals that showed stable performance of the PR schedule. Stable performance was defined as 4 consecutive days of cocaine self-administration with break points within a range of four. The testing order of the various dosages of baclofen was counterbalanced according to a latinized design. At least 4 days of baseline training separated baclofen test days.

\section{Experiment 2}

Subjects $(N=10)$ were trained on the PR schedule as described above. The effect of $( \pm)$-baclofen pretreatment $(2.5 \mathrm{mg} / \mathrm{kg} / \mathrm{IP}, 30$ minutes before the session) was examined across four unit injection doses of cocaine $(0.18,0.38,0.75,1.5 \mathrm{mg} / \mathrm{kg} / \mathrm{inj})$. The testing order of the cocaine doses was counterbalanced according to a latinized design. Extensive experience with the PR schedule has shown that the doses of cocaine selected represent the ascending limb of the dose/response curve. The $0.18 \mathrm{mg} / \mathrm{kg} / \mathrm{inj}$ dose is near threshold and usually supports a total of 30 to 40 responses/session. The highest dose can be expected to support about 300 to 400 responses/session, which is equivalent to a final ratio of about 77 . Doses above $1.5 \mathrm{mg} / \mathrm{kg} /$ inj can be toxic and generally do not support higher break points. The effect of baclofen was examined after a stable baseline (see above) was established at each dose.

\section{Experiment 3}

Subjects $(N=5)$ were trained to self-administer cocaine $(1.5 \mathrm{mg} / \mathrm{kg} / \mathrm{inj})$ on an FR 1 schedule during daily 5-hour sessions. The effect of baclofen $(2.5 \mathrm{mg} / \mathrm{kg}$, IP, $30 \mathrm{~min}-$ 
utes before the session) or vehicle injections (saline) was examined. The dependent measure was the number of injections self-administered during each hour period.

\section{Experiment 4}

Subjects $(N=8)$ were food deprived and trained to respond on a PR schedule for food reinforcement $(45 \mathrm{mg}$ Noyes pellets). Animals were given access to food ( $\mathrm{Pu}-$ rina Rat Chow) for 1 hour after each training session. Rats on this deprivation schedule remain healthy and gain weight at approximately $1 \mathrm{~g} /$ day, yet are highly motivated to respond for food. The testing apparatus was identical to that used in self-administration experiments described above. The PR schedule was also identical to that described above. That is, delivery of the first reinforcement was contingent on a single lever response, thereafter the ratio of responses required to obtain the food pellet was incremented through the progression: 1, 2, 4, 6, 9, 12, 15, 20, 25, 32, 40, 50, 62, 77, 95, $118,145,178,219,268,328,402,492,603$. The session duration was 3 hours. Break point was defined by the number of completed increments in the schedule. The effect of baclofen (1.25, 2.5 and 5.0, IP, 30 minutes before the session) or vehicle (saline) was examined in a random order. Drug test days were separated by at least three baseline sessions.

\section{Statistics}

Data for each experiment were subjected to a repeated measures ANOVA, followed, when appropriate, by Neuman-Keuls analysis.

\section{RESULTS}

Figure 1 shows the effect of various doses of baclofen $(1.25,2.5,5.0 \mathrm{mg} / \mathrm{kg})$ on cocaine self-administration behavior reinforced on a PR schedule. Repeated measures ANOVA revealed a significant effect of DOSE $(F=13.5$, $d f=3.21, p<.01)$, indicating a dose-dependent decrease in the break point produced by baclofen.

Figure 2 illustrates the effect of baclofen $(2.5 \mathrm{mg} / \mathrm{kg})$ on cocaine self-administration behavior in a representative animal. Baseline responding (Figure 2, top) is characterized by an alternating pattern of postinfusion pauses and bursts of the requisite number of responses. Baclofen pretreatment (Figure 2, bottom) reduced the break point without affecting the general response pattern.

Figure 3 shows the effect of baclofen pretreatment $(2.5 \mathrm{mg} / \mathrm{kg})$ across a series of unit injection doses of cocaine. Repeated measures ANOVA revealed a significant effect of DRUG ( $F=25.6, d f=1,18, p<.01)$. Neu-

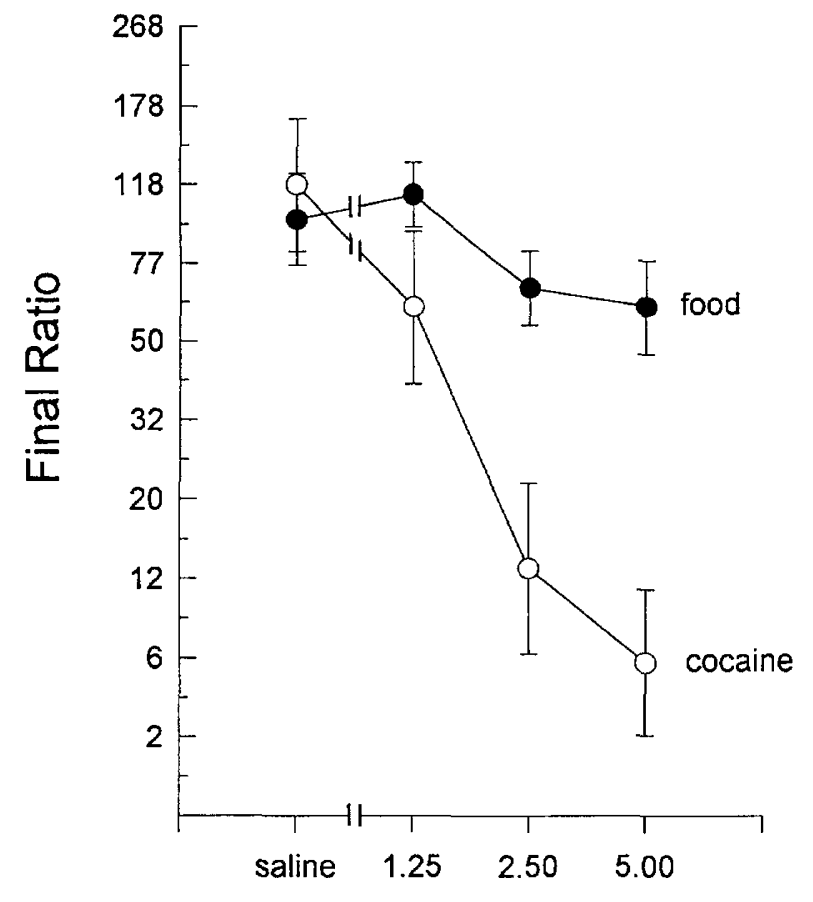

\section{Baclofen Dose (mg/kg)}

Figure 1. Effect of baclofen on responding for either cocaine or food reinforcement. Points represent the mean ( \pm SEM) break points established on a PR schedule for separate groups of animals trained to respond for either cocaine $(N=12)$ or food $(N=8)$ reinforcement. Animals received various doses of baclofen or vehicle 30 minutes before the test session. Baclofen pretreatment produced a dose-dependent decrease in break points for cocaine and food reinforcement, although by comparison, the effect on food reinforced responding was quite small.

man-Keuls analysis revealed a significant decrease in break point at each of the unit doses of cocaine $(0.18$, $0.38,0.75,1.5, \mathrm{mg} / \mathrm{kg} / \mathrm{inj}$ ).

Figure 1 illustrates the effect of baclofen on food reinforced responding. Baclofen produced modest but statistically significant effects on responding on a PR schedule $(\mathrm{F}=4.5, d f=3,21, p<.05)$. Table 1 shows the effect of baclofen on cocaine self-administration reinforced on an FR 1 schedule. Repeated measures ANOVA revealed no significant effects of baclofen on rate of drug intake $(\mathrm{F}<1)$.

\section{DISCUSSION}

The PR schedule provides a sensitive paradigm with which to study cocaine self-administration. The dependent variable, break point, yields a robust dose/response curve on which pharmacological and neurotoxic manipulations can be assessed. Break point is linearly proportional to unit injection dose of cocaine up to 1.5 

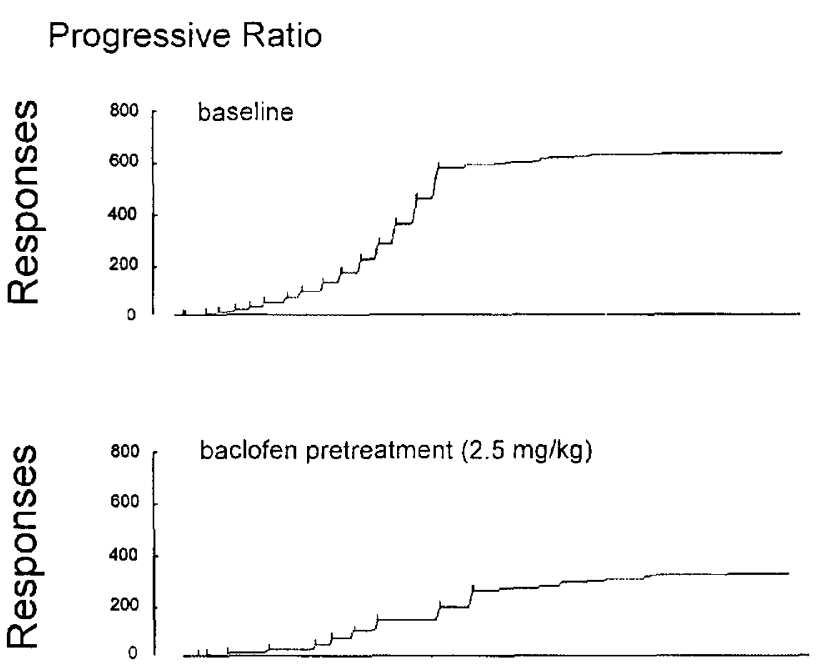

Fixed Ratio 1

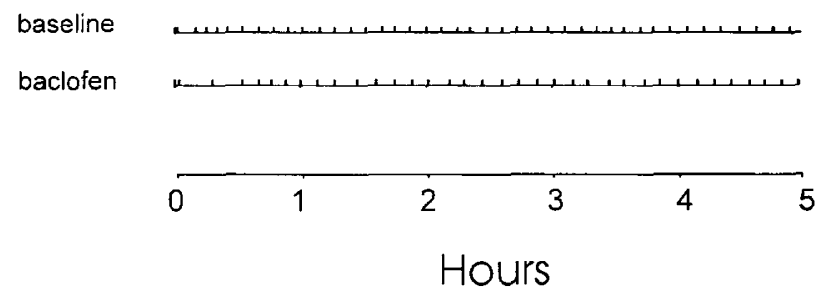

Figure 2. Representative records illustrating the effect of baclofen on cocaine self-administration reinforced on either a PR or FR schedule of reinforcement. The top two lines represent cumulative records of cocaine self-administration on a PR schedule. Upward increments in the record represent lever responses. Short vertical lines represent cocaine infusions. The top record illustrates a baseline pattern of intake. In this case, the animal self-administered 16 injections, which corresponds to a final ratio of 118. After baclofen treatment $(2.5 \mathrm{mg} / \mathrm{kg})$, the same animal self-administered 10 injections, which corresponds to a final ratio of 32 . In this example, the break points occurred at approximately the same time into the session. In other animals, baclofen may have produced a break point earlier (if there were no substantial pauses) or later (if the pattern was interrupted). The bottom two lines illustrate the regular pattern of cocaine intake on an FR 1 schedule. Tick marks indicate the time of each cocaine injection $(1.5 \mathrm{mg} / \mathrm{kg} / \mathrm{inj})$. Baclofen pretreatment had minimal effects on the pattern.

$\mathrm{mg} / \mathrm{kg} / \mathrm{inj}$ (Depoortere et al. 1993; Richardson and Roberts 1995), past which performance declines or becomes variable. Responding on the PR schedule has been shown to be affected either by ibotenic acid lesions (Robledo and Koob 1993) or by 6-hydroxydopamine lesions of the nucleus accumbens (Koob et al. 1987), medial prefrontal cortex, or amygdala (McGregor and Roberts 1994, 1995a), as well as systemic (Hubner and Moreton 1991; Depoortere et al. 1993; Roberts et al. 1989b; Smith et al. 1995; Richardson et al. 1994) and in-

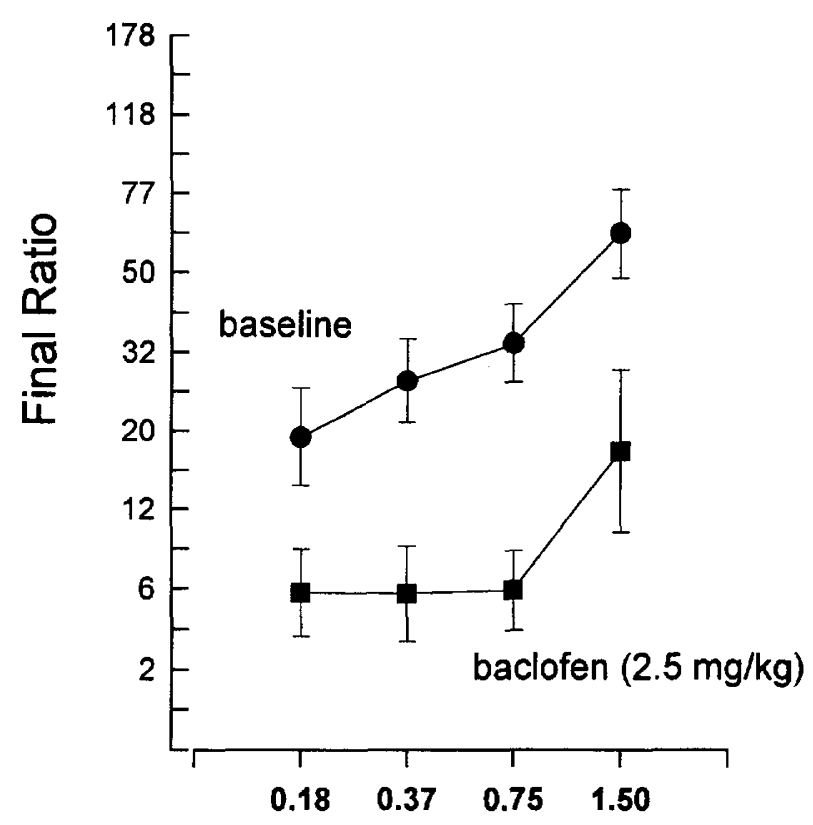

\section{Cocaine Dose (mg/kg/inj)}

Figure 3. Effect of baclofen $(2.5 \mathrm{mg} / \mathrm{kg})$ on cocaine selfadministration reinforced on a PR schedule. Points represent the mean $( \pm$ SEM) break point for a single group of rats $(N=$ 10) during baseline testing (circles) or after baclofen pretreatment $(2.5 \mathrm{mg} / \mathrm{kg} \mathrm{IP})$. Break points were defined by the number of completed increments in the PR series. The final ratios corresponding to the break points are shown on the abscissa.

tracerebral injections (McGregor and Roberts 1993, $1995 b)$ of dopamine antagonists.

To date, few experiments have investigated the effects of GABA manipulations on cocaine reinforcement. The present results show that acute pretreatment with the $\mathrm{GABA}_{\mathrm{B}}$ agonist baclofen decreases cocaine self-administration on a PR schedule in rats. Experiment 1 demonstrated a dose-dependent effect of baclofen. The two higher doses $(2.5$ and $5 \mathrm{mg} / \mathrm{kg}$ ) produced significant decreases in break point when tested against a single unit injection dose of cocaine. In experiment 2, a single dose of baclofen $(2.5 \mathrm{mg} / \mathrm{kg})$ was tested across the cocaine dose-response curve. Baclofen was found to reduce break point at every cocaine dose tested.

It should be considered that the baclofen-induced decrease in cocaine self-administration might be due to a sedative or debilitating effect on performance. Whereas baclofen is known to have some depressant properties, it is unlikely that this would explain the magnitude of the effect on cocaine-reinforced responding, particularly at the $2.5 \mathrm{mg} / \mathrm{kg}$ dose. Baclofen was found to produce a statistically significant but relatively modest effect on break points when food was used as a reinforcer, even at a relatively high dose of $5.0 \mathrm{mg} / \mathrm{kg}$ (see Figure 
Table 1. Effect of Baclofen $(2.5 \mathrm{mg} / \mathrm{kg})$ on Cocaine Self-Administration Reinforced on a Fixed Ratio 1 Schedule

\begin{tabular}{lccccc}
\hline & \multicolumn{5}{c}{ Hour } \\
\cline { 2 - 6 } & $\mathbf{1}$ & $\mathbf{2}$ & $\mathbf{3}$ & $\mathbf{4}$ & $\mathbf{5}$ \\
\hline Vehicle & $8.4 \pm 0.5$ & $7.1 \pm 0.8$ & $7.1 \pm 0.5$ & $6.9 \pm 0.5$ & $7.0 \pm 0.6$ \\
Baclofen & $7.2 \pm 0.8$ & $7.2 \pm 0.4$ & $7.0 \pm 0.4$ & $7.0 \pm 0.4$ & $7.2 \pm 0.5$ \\
\hline
\end{tabular}

Data represent the mean $( \pm$ SEM) number of injections self-administered during each hour of a 5-hour session. The same group of rats $(\mathrm{N}=5)$ was pretreated with either baclofen $(2.5 \mathrm{mg} / \mathrm{kg})$ or vehicle (saline) 20 minutes before the session. The unit injection dose of cocaine was $1.5 \mathrm{mg} / \mathrm{kg} / \mathrm{inj}$. No statistically significant differences were observed.

1). However, a survey of the literature shows that baclofen can affect performance in some laboratory situations. Doses as low as $1.25 \mathrm{mg} / \mathrm{kg}$ have been shown to reduce locomotor activity in rats with $5.0 \mathrm{mg} / \mathrm{kg}$ producing about a $70 \%$ reduction in spontaneous activity (Paredes and Agmo 1989; McManus and Greenshaw 1991). Significant effects of baclofen ( 2.5 and $5.0 \mathrm{mg} / \mathrm{kg}$ ) were found on some aspects of precopulatory behavior, although a dose of $5.0 \mathrm{mg} / \mathrm{kg}$ was necessary to inhibit copulation. Grech and Balster (1993) reported that the $\mathrm{ED}_{50}$ for the response rate decreasing effects of baclofen was $5.0 \mathrm{mg} / \mathrm{kg}$ in a two-lever drug discrimination task. It appears that baclofen can produce disruptive effects on performance, particularly at high doses. However, the ability of animals to perform relatively well in operant tasks at the lower doses seems to indicate that a drug-induced motor impairment cannot account for the effect on cocaine self-administration reported here. In summary, it appears that low doses of baclofen may produce a relatively specific reduction in the motivation of animals to self-administer cocaine.

It should be noted that baclofen may have reinforcing effects on its own and this property could interact with cocaine reinforcement. Griffiths et al. (1991) examined baclofen self-administration in baboons and reported that baclofen maintained intermediate rates of self-injection, although these "were variable and did not show consistent dose related changes across animals." Given that there have been few reports of baclofen abuse in the human population, it is unlikely that the reinforcing effects of baclofen are particularly robust.

Baclofen pretreatment had no effect on cocaine selfadministration reinforced on an FR 1 schedule. A substantial literature has been based on evaluating drug effects by examining changes in rate of drug intake. However, it now appears that changes in rate of drug intake may be insensitive to changes in reinforcing efficacy as measured by the PR schedule. In general, break point and rate are inversely related. For example, decreases in break point and increases in rate are observed when the unit injection dose of cocaine is reduced or when animals are pretreated with dopamine antagonists (Depoortere et al. 1993; Hubner and Morton 1991; Loh et al. 1992; Richardson and Roberts 1994). However, treat- ments have now been observed that dramatically increase or decrease break point, yet have no effect on rate of drug intake (Koob et al. 1987; Roberts et al. 1989a; Hubner and Koob 1990; Richardson and Roberts 1991; Smith et al. 1995; McGregor and Roberts 1995a). This disparity is particularly evident if the treatment is nondopaminergic. The fact that baclofen had no effect on rate of drug intake is not unexpected in light of the growing literature showing a dissociation between changes in reinforcing efficacy and rate of drug intake (Roberts et al. 1989a; Loh and Roberts 1990; McGregor et al. 1993; Smith et al. 1995).

It is presently unclear how $\mathrm{GABA}_{\mathrm{B}}$ agonists produce an apparent reduction in the reinforcing efficacy of $\mathrm{CO}^{-}$ caine. After systemic injections, the drugs would gain access to GABA receptors, which are distributed ubiquitously throughout the neural axis. However, given the importance of the mesolimbic DA system to cocaine reinforcement and given the powerful interactions between DA and GABA (see Kalivas 1993), it is possible that the effects are mediated through an interaction with VTA neurons. Both $\mathrm{GABA}_{\mathrm{A}}$ and $\mathrm{GABA}_{\mathrm{B}}$ receptors are present in the VTA, and pharmacological manipulation of these receptors has been reported to affect reinforced behavior. Willick and Kokkinidis (1995) have shown that intra-VTA injections of baclofen significantly increase current thresholds for medial forebrain bundle self-stimulation. Although these authors reported no specific effect of the $\mathrm{GABA}_{\mathrm{A}}$ agonist muscimol on reward thresholds, Nazzaro and Gardner (1980) have previously reported that intra-VTA injections of the $\mathrm{GABA}_{\mathrm{A}}$ antagonist picrotoxin decreased current thresholds. The present results suggest that modulation of $\mathrm{GABA}_{\mathrm{B}}$ receptors can affect cocaine reinforcement. These findings have been replicated with another $\mathrm{GABA}_{\mathrm{B}}$ agonist, SKF 97541, which reduces cocaine selfadministration on a PR schedule at doses that do not affect food reinforced responding. Muscimol, a $G_{A B A}$ agonist, has similar but less specific effects (in preparation). Thus, both receptor subtypes may modulate reward function, although the $\mathrm{GABA}_{\mathrm{A}}$ effect appears to be more robust.

No substantially effective treatment is presently available for cocaine dependence (Kleber 1995). The 
major emphasis in medication development has focused on dopaminergic compounds. The present data suggest that nondopaminergic agents, particularly GABA-related drugs, should also be considered for their pharmacotherapeutic potential in cocaine addiction.

\section{ACKNOWLEDGMENTS}

This work was supported by NIDA contract No. NO1DA-37302 .

\section{REFERENCES}

Caine SB, Koob GF (1994): Effects of dopamine D-1 and D-2 antagonists on cocaine self-administration under different schedules of reinforcement in the rat. J Pharmacol Exp Ther 270:209-218

Cameron DL, Williams JT (1993): dopamine D1 receptors facilitate transmitter release. Nature 366:344-347

De Wit H, Wise RA (1977): Blockade of cocaine reinforcement in rats with the dopamine receptor blocker pimozide, but not with noradrenergic blockers phentolamine and phenoxybenzamine. Can J Psych 31:195-203

Depoortere RY, Li DH, Lane JD, Emmett-Oglesby MW (1993): Parameters of self-administration of cocaine in rats under a progressive-ratio schedule. Pharmacol Biochem Behav 45:539-548

Engberg G, Klingpetersen T, Nissbrandt H (1993): GABA(B) receptor activation alters the firing pattern of dopamine neurons in the rat substantia nigra. Synapse 15:229-238

Goeders NE, McNulty MA, Guerin GF (1993): Effects of alprazolam on intravenous cocaine self-administration in rats. Pharmacol Biochem Behav 44:471-474

Goeders NE, McNulty MA, Mirkis S, McAllister KH (1989): Chlordiazepoxide alters intravenous cocaine self-administration in rats. Pharmacol Biochem Behav 33:859-866

Grech DM, Balster RL (1993): Pentobarbital-like discriminative stimulus effects of direct GABA agonists in rats. Psychopharmacology 110:295-301

Griffiths RR, Lamb RJ, Sannerud CA, Ator NA, Brady JV (1991): Self-Injection of barbiturates, benzodiazepines and other sedative-anxiolytics in baboons. Psychopharmacology 103;154-161

Hubner CB, Koob GF (1990): The ventral pallidum plays a role in mediating cocaine and heroin self-administration in the rat. Brain Res 508:20-29

Hubner CB, Moreton JE (1991): Effects of selective D1 and D2 dopamine antagonists on cocaine self-administration in the rat. Psychopharmacology 105:151-156

Johanson C-E, Fischman MW (1989): The pharmacology of cocaine related to its abuse. Pharmacol Rev 41:3-52

Kalivas PW (1993): Neurotransmitter regulation of dopamine neurons in the ventral tegmental area. Brain Res Rev 18:75-113

Kita H, Kitai ST (1988): Glutamate decarboxylase immunoreactive neurons in rat neostriatum: Their morphological types and populations. Brain Res 447:346-352
Kleber HD (1995): Pharmacotherapy, current and potential, for the treatment of cocaine dependence. Clin Neuropharmacol 18:S96-S109

Klitenick MA, Dewitte P, and Kalivas PW (1992): Regulation of somatodendritic dopamine release in the ventral tegmental area by opioids and GABA: An in vivo microdialysis study. J Neurosci 12:2623-2632

Koob GF (1992): Drugs of abuse: Anatomy, pharmacology and function of reward pathways. Trends Pharmacol Sci $13: 177-184$

Koob GF, Vaccarino FJ, Amalric M, Bloom FE (1987): In pp 35-50 Brain Reward Systems and Abuse. New York, Engel J, Oreland L, (eds), Raven Press.

Loh EA, Fitch T, Vickers GJ, Roberts DCS (1992): Clozapine increases breaking points on a progressive-ratio schedule reinforced by intravenous cocaine. Pharmacol Biochem Behav 42:559-562

Loh EA, Roberts DCS (1990): Break-points on a progressive ratio schedule reinforced by intravenous cocaine increases following depletion of forebrain serotonin. Psychopharmacology 101:262-266

Maldonado R, Robledo P, Chover AJ, Caine SB, Koob GF (1993): $D_{1}$ dopamine receptors in the nucleus accumbens modulate cocaine self-administration in the rat. Pharmacol Biochem Behav 45:239-242

McGregor A, Roberts DCS (1993): Dopaminergic antagonism within the nucleus accumbens or the amygdala produces differential effects on intravenous cocaine selfadministration under fixed and progressive ratio schedules of reinforcement. Brain Res 624:245-252

McGregor A, Roberts DCS (1994): Effect of 6-hydroxydopamine lesions of the amygdala on intravenous cocaine self-administration under a progressive ratio schedule of reinforcement. Brain Res 646:273-278

McGregor A, Roberts DCS (1995a): Effect of medial prefrontal cortex injections SCH 23390 on intravenous cocaine self-administration under both a fixed and progressive ratio schedule of reinforcement. Behav Brain Res 67: 75-80

McGregor A, Roberts DCS (1995b): Effect of 6-hydroxydopamine lesions of the medial prefrontal cortex on intravenous cocaine self-administration under a progressive ratio schedule of reinforcement. Pharmacol Biochem Behav 52, in press

McManus DJ, Greenshaw AJ (1991): Differential effects of chronic antidepressants in behavioral tests of beta-adrenergic and $\mathrm{GABA}_{B}$ receptor function. Psychopharmacology 103:204-208

Nazzaro J, Gardner EL (1980): GABA antagonism lowers self-stimulation thresholds in the ventral tegmental area. Brain Res 189:279-283

Paredes R, Agmo A (1989): Stereospecific actions of baclofen on sociosexual behavior, locomotor activity and motor execution. Psychopharmacology 97:358-364

Richardson NR, Piercey MF, Svensson K, Collins RJ, Myers JE, Roberts DCS (1993): Antagonism of cocaine selfadministration by the preferential dopamine autoreceptor antagonist, (+)-AJ 76. Brain Res 619:15-21

Richardson NR, Roberts DCS (1991): Fluoxetine pretreatment reduces breaking points on a progressive ratio 
schedule reinforced by intravenous cocaine self-administration in the rat. Life Sci 49:833-840

Richardson NR, Roberts DCS (1995): Implementation of progressive ratio schedules of reinforcement in drug selfadministration studies in rats. J Neurosci Methods (in press)

Richardson NR, Smith AM, Roberts DCS (1994): A single injection of either flupenthixol decanoate or haloperidol decanoate produces long-term changes in cocaine selfadministration in rats. Drug Alcohol Depend 36:23-25

Rick CE, Lacey MG (1994): Rat substantia nigra pars reticulata neurons are tonically inhibited via $\mathrm{GABA}(\mathrm{A})$, but not $\mathrm{GABA}(\mathrm{B})$, receptors in vitro. Brain Res 659:133-137

Ritz MC, Lamb RJ, Goldberg SR, Kuhar MJ (1987): Cocaine receptors on dopamine transporters are related to selfadministration of cocaine. Science 237:1219-1223

Roberts DCS (1992): Neural substrates mediating cocaine reinforcement. In Lakoski JM, Galloway MP, White FJ (eds), Cocaine: Pharmacology, Physiology and Clinical Strategies. Boca Raton, FL, CRC Press, pp 73-90

Roberts DCS, Bennett SAL, Vickers GJ (1989a): The estrous cycle affects cocaine self-administration on a progressive ratio schedule in rats. Psychopharmacology 98:408411

Roberts DCS, Corcoran ME, Fibiger HC (1977): On the role of ascending catecholamine systems in intravenous selfadministration of cocaine. Pharmacol Biochem Behav 6:615-620

Roberts DCS, Goeders N (1989): Drug self-administration: Experimental methods and determinants. In Boulton AA, Baker GB, Greenshaw AJ (eds), Neuromethods: Psychopharmacology. Human Press, Clifton, NJ, pp 349-398

Roberts DCS, Koob GF, Klonoff P, Fibiger HC (1980): Extinction and recovery of cocaine self-administration following 6-hydroxydopamine lesions of the nucleus accumbens. Pharmacol Biochem Behav 12:781-787

Roberts DCS, Loh EA, Vickers GJ (1989b): Self-administration of cocaine on a progressive ratio schedule in rats: Dose-response relationship and effect of haloperidol pretreatment. Psychopharmacology 97:535-538

Roberts DCS, Vickers GJ (1984): Atypical neuroleptics increase self-administration of cocaine: An evaluation of a behavioral screen for antipsychotic drug activity. Psychopharmacology 82:135-139
Robledo P, Koob GF (1993): Two discrete nucleus accumbens projection areas differentially mediate cocaine self-administration in the rat. Behav Brain Res 55:159-166

Santiago M, Cano J, Westerink BHC (1993a): Are bilateral nigrostriatal dopaminergic pathways functionally linked in the rat brain: A microdialysis study in conscious rats. Brain Res 628:187-192

Santiago M, Machado A, Cano J (1993b): Regulation of the prefrontal cortical dopamine release by $\operatorname{GABA}(\mathrm{A})$ and $\mathrm{GABA}(\mathrm{B})$ receptor agonists and antagonists. Brain Res 630:28-31

Santiago M, Machado A, and Cano J (1993c): In vivo release of dopamine from rat striatum, substantia nigra and prefrontal cortex: Differential modulation by baclofen. Br J Pharmacol 109:814-818

Seutin V, Johnson SW, North RA (1994): Effect of dopamine and baclofen on N-methyl-D-aspartate induced burst firing in rat ventral tegmental neurons. Neuroscience 58:201-206

Smith AM, Piercey M, Roberts DCS (1995): The effect of (-)-DS 121 and $(+)$-UH 232 on cocaine self-administration in rats. Psychopharmacology 120:93-98

Westerink BHC, Santiago M, Devries JB (1992): In vivo evidence for a concordant response of terminal and dendritic dopamine release during intranigral infusion of drugs. Naunyn-Schmied Arch Pharmacol 356:637-643

Willick ML, Kokkinidis L (1995): The effects of ventral tegmental administration of $\mathrm{GABA}_{A}, \mathrm{GABA}_{B}$ and NMDA receptor agonists on medial forebrain bundle self-stimulation. Behav Brain Res 70:31-36

Woolverton WL (1986): Effects of a D1 and D2 dopamine antagonist on the self-administration of cocaine and piribedil by rhesus monkeys. Pharmacol Biochem Behav 24:531-535

Woolverton WL, Johnson KM (1992): Neurobiology of cocaine abuse. Trends Pharmacol Sci 13:193-200

Yoshida M, Yokoo H, Tanaka T, Emoto H, Tanaka M (1994): Opposite changes in the mesolimbic dopamine metabolism in the nerve terminal and cell body sites induced by locally infused baclofen in the rat. Brain Res 636:111114

Zito KA, Vickers GJ, Roberts DCS (1985): Disruption of cocaine and heroin self-administration following kainic acid lesions of the nucleus accumbens. Pharmacol Biochem Behav 23:1029-1036 